\title{
RECONSTRUCTING THE IDEA OF PRAYER SPACE: A CRITICAL ANALYSIS OF THE TEMPORARY PRAYING PLATFORM PROJECT OF 2ND YEAR ARCHITECTURE STUDENTS IN THE NATIONAL UNIVERSITY OF MALAYSIA (UKM)
}

Dr. Nangkula Utaberta

Mohammad Arsyad Bahar
ProfesorMadya, Universiti Putra Malaysia (UPM)

Serdang, Selangor, Malaysia

nangkula_arch@yahoo.com

Universiti Kebangsaan Malaysia (UKM)

Bangi, Selangor, Malaysia

arsyad.bahar@gmail.com

\begin{abstract}
God created human as caliph on this earth. Caliph means leader, care-taker and guardian. Therefore humans have an obligation to maintain, preserve and conserve this natural for future generations. Today we see a lot of damage that occurs in the earth caused by human behavior. Islam saw the whole of nature as a place of prayer that must be maintained its cleanliness and purity. Therefore as Muslims we need to preserve nature as we keep our place of prayer. The main objective of this paper is to re-questioning and re-interpreting the idea of sustainability in Islamic Architecture through a critical analysis of first project of 2nd year architecture student of UKM which is the "Temporary Praying Platform". The discussion itself will be divided into three (3) main parts. The first part will be discussing contemporary issues in Islamic Architecture especially in the design of Mosques while the second part will expand the framework of sustainability in Islamic Architecture. The last part will be analyzing some sample of design submission by 2nd year students of UKM on the temporary praying platform project. It is expected that this paper can start a further discussion on the inner meaning in Islam and how it was implemented in the design of praying spaces in the future.
\end{abstract}

Keywords: Sustainability, Islamic Architecture, Temporary Praying Platform

\begin{abstract}
Abstrak
Tuhan menciptakan manusia sebagai khalifah di muka bumi ini. Khalifah berarti pemimpin, penjaga dan wali. Oleh karena itu, manusia memiliki kewajiban untuk memelihara, menjaga dan melestarikan alam ini untuk generasi mendatang. Sekaranginikitatelahmelihat banyak kerusakan yang terjadi di bumi yang disebabkan oleh perilaku manusia itu sendiri yang disebutkan sebagai khalifah di bumi. Islam melihat seluruh alam sebagai tempat beribadah yang harus dijaga kebersihan dan kemurniannya, oleh karena itu, sebagai umat Islam adalah perlu melestarikan alam seperti menjaga tempat ibadah mereka. Tujuan utama dari makalah ini adalah untuk mempertanyakan dan menafsirkan kembali gagasan keberlanjutan (sustainable) dalam Arsitektur Islam melalui analisis kritis tugas pertama dari mahasiswa arsitektur angkatan tahun kedua dari Universiti Kebangsaan Malaysia (UKM), yaitu tugas perancangan " tempat beribadah sementara "atau "temporary praying platform" . Kajiandibagi menjadi tiga bagian utama. Bagian pertama akan membahas isu-isu kontemporer dalam Arsitektur Islam terutama dalam desain masjid. Kajian kedua adalah kerangka keberlanjutan dalam arsitektur Islam. Bagian ketiga adalah analisis dari beberapa sampel pengajuan desain oleh mahasiswa. Diharapkan tulisan ini dapat memulai diskusi lebih lanjut tentang makna batin dalam Islam dan bagaimana penerapannya dalam desain ruang beribadah yang sustainable.
\end{abstract}

Kata kunci:Keberlanjutan, Arsitektur Islam, tempat beribadah sementara

\section{Introduction}

The main objective of this paper is to requestioning and re-interpreting the idea of sustainability in Islamic Architecture through a critical analysis of first project of $2^{\text {nd }}$ year architecture student of UKM which is the "Temporary Praying Platform". The discussion itself will be divided into three (3) main parts. The first part will be discussing contemporary issues in Islamic Architecture especially in the design of Mosques 
while the second part will expand the framework of sustainability in Islamic Architecture. The last part will be analyzing some sample of design submission by $2^{\text {nd }}$ year students of UKM on the temporary praying platform project. It is expected that this paper can start a further discussion on the inner meaning in Islam and how it was implemented in the design of praying spaces in the future.

\section{Key Issues Islamic Architecture in Nusantara}

This section will attempt to explain the various issues that are used as the principle of the classification process within the art community of Islam. These issues are very important because they are used to understand and interpret the arts of the Islamic community, particularly in the Nusantara. There are at least six (6) key issues regarding the documentation and the interpretation of Islamic architecture in Nusantara: the history of how the community used the product in the past; the interpretation of the principles of Islamic law; the need to be compatible with the contemporary spirit and local ideas about progress; issues of symbolism; the interpretation of the value of the object; and the issue of building typology.

\section{Issues with the Past Use of Historical Products}

The first issue that became the basis of various studies on Islamic architecture concerned the historical use of the product. Some thinkers and researchers of the Islamic architecture of the Muslim community believe that the history of a building is an important issue that must be studied to understand the concept and philosophy of Islamic architecture.

At the same time, a number of other researchers believe the contrary. They believe that buildings from the Muslim community before the birth were a product not of Islamic thought, but, on the contrary, of tradition and the social-political or the Muslim community. These researchers saw that a survey on historic Islamic buildings would not give a formula of Islamic architecture and would actually only be an image formation.

Those who believe in accepting the use of historical sources are divided in their opinions as to whether any part of Islam can be considered to reflect the history of Islam. Most of the historical success of Islam during times such as Islam's rise in Turkey and the time of SafafidUstmani is considered a suitable reference of the history of Islam. The early days of Islam itself, concerning the Prophet and his companions, are often considered a forbidden time, too important to be consulted in terms of architecture. This is clearly stated by Cresswell in the following:

"Arabia, at the rise of Islam, does not appear to have possessed anything worthy of the name of architecture. Only a small portion of the population was settled, and these lived in dwellings which were scarcely more than hovels." 1

"Such was the house of the leader of the community at Medina. Nor did Muhammad wish to alter these conditions; he was entirely without architectural ambitions, and Ibn Sa'd records the following saying of his: "The most unprofitable thing that eateth up the wealth of a Believer is building."2

Those who oppose studying the past use of historical buildings and objects have been divided between studying only the aspects of the architecture and using the internal framework of Islam using the Qur'an and the Sunnah as reference sources. The parties useijtihad and interpretation as a design deemed suitable for use in the future. The use of ijtihad and interpretation derives from the feeling that the basic principles of Islam are not clearly regulated in architecture because if they were, there would be no need for further ijtihad and interpretation, as in the following opinion from Serageldin:

"I do not believe that any reading of the Qur'an, at any level, or a study of the Sunna, will providea detailed instructions on how to design a house in Morocco or Indonesia, or how to design the thoroughfares of Cairo or Istanbul. Those that have tried to derive specific examples from these source are doing both themselves and the sources a disfavour. Themselves by ignoring the wider context in which we live and which must provide the major "givens" of the problems to be addressed, and the sources by demeaning them to the level of a "handbook" or "textbook" rather than treating Qur'an as eternal message of inspiration and guidance for all times and the Sunna of the Prophet as the embodiment of exemplary behaviour. If God had desire to give people specific instructions on how to build structures in the twentieth century, He could certainly have done so explicitly."

Figure 1 is the example of different views that can be seen at the Kocatepe mosque design in Turkey. In the design of the mosque, it can be 
clearly seen how a design with a modern approach, as was done by VedatDalokay's contest-winning mosque, has been replaced by a revivalist version of the Turkish buildings in the past.

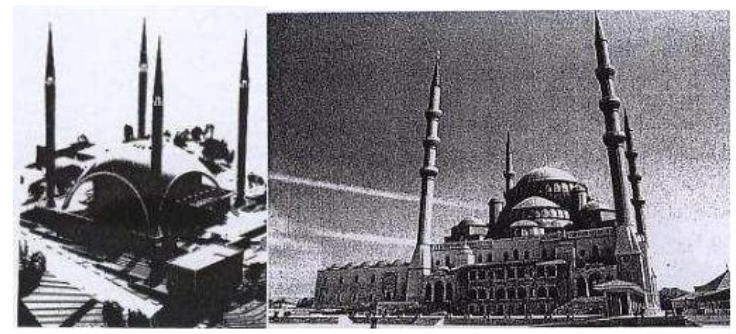

Figure 1: Kocatepe Mosque in Turkey; on the left is the design that won the VedatDalokay contest, while the right is the mosque that was finally built.

\section{The issue of interpretation of the Basic Laws of Islam}

Another issue that is often the basis of various studies on Islamic architecture is that of the interpretation of the laws of Islam. Some scholars of Islamic architecture believe that Islam is a religion that is already complete and perfect. Therefore, there is no further study needed from outside of the sciences of Islam. With this understanding, the researchers do not see the need to review any aspects that are not considered appropriate, particularly against Muslims, with the concern that these aspects would destroy the purity of the teachings of Islam itself.

Other researchers see Islamic law as a legal framework that is complete and therefore perfect, especially in terms of worship, and that no longer needs additions and corrections. In terms of thinking, the researchers believe that Islamic thought is the result of the interaction between the fundamental laws of Islam and the situation existing in the environment. Therefore, Islamic thought must always be improved and updated to make it consistent with the contemporary community. Various opinions and interpretations of Islamic law form a foundation and affect the thoughts and theories that areproducedregarding Islamic architecture $^{4}$.

The Need to be Compatible with the Spirit of the Time, the Spirit of the Place and the Idea of Progress

Another issue is the need to produce architecture in accordance with the contemporary soul and spirit. This issue is closely related to the previous issues, particularly the issues concerning the interpretation of the basic laws of Islam.

Every era requires its own form and character. Therefore, the ideas and character of the old buildings cannot be used again today. Times have changed, the needs of each individual have changed, and we cannot use the architecture that was born out of the situations and circumstances of the past (which is defined differently) for the situations and circumstances that exist today. This opinion can be seen in the statements of Viollet Le Duc and Walter Gropius that follow:

"Suppose that an Architect of the Twelfth or thirteenth century were to return among us, and that he were to be initiated into our moden idea; if one put at his disposal the perfection of moden industry, he would not build an edifice of the time of Philip Augustus or St. Louis, because this world be to falsify the first law of art, which is to conform to the needs and customs of the time (Viollet Le Duc)."

'Today's artist lives in an era of dissolution without guideance. He stand alone. The old form are in ruins, the benumbered world is shaken up, the old human spirit is invalidated and in flux towards a new form. We float in space and cannot perceive the new form. (Walter Gropius)." "6

One of the main ideas born from this concept is the idea of progress. As modern men, we have to progress to meet the needs and tastes of this age. Although often more similar to material achievements, the idea is for us to move in accordance with the situation and the age. The idea of progress has greatly influenced the subsequent thinking about the architecture of Islam, especially concerning the design, the selection of materials, and the architectural language used.

The spirit of contemporary issues related to the architectural language, material selection and use of a building system should be compatible with the building settlement. Each district and area has a character and a culture all its own. Therefore, the design of a building should be prepared to grapple with these issues.

\section{Issues and Interpretation of Symbolism}

Another critical issue affecting a variety of thoughts and ideas regarding Islamic architecture is ideas and thoughts about symbolism. Some scholars suggest that spiritual and religious devoutness should be interpreted and realised in the form of symbols, which will increase feelings of faith and devotion in the people who use the building. The symbols chosen are usually elements that represent Islam. Elements such as domes, towers, arches, and calligraphy are among the few elements that are considered to be representative and characteristic of Islamic architecture.

In addition to the elements, monumental and romantic space is often planned into the various buildings that are considered representative of Islamic architecture. Ambiance is usually a grand and solemn character that has been a primary part of the design of a mosque or a building with Islamic 
character. With an understanding of aspects of Islamic holy reason, the design is ordered to meet a variety of additional needs besides the basic functionality.

Masjid UniversitiTeknologi Malaysia is an example of how the issue of implementation is a symbol of architectural styles. In the design of this mosque, we can see the various elements, such as the Dome of the Isfahan era of architecture, Iran's arch Iwan, the pulpit in the Cairo mosque, Mashrabiya, and the poles to support the North African-style towers of Istanbul, Turkey. All these various architectural styles have been applied to this mosque, as can be seen in picture 2 .

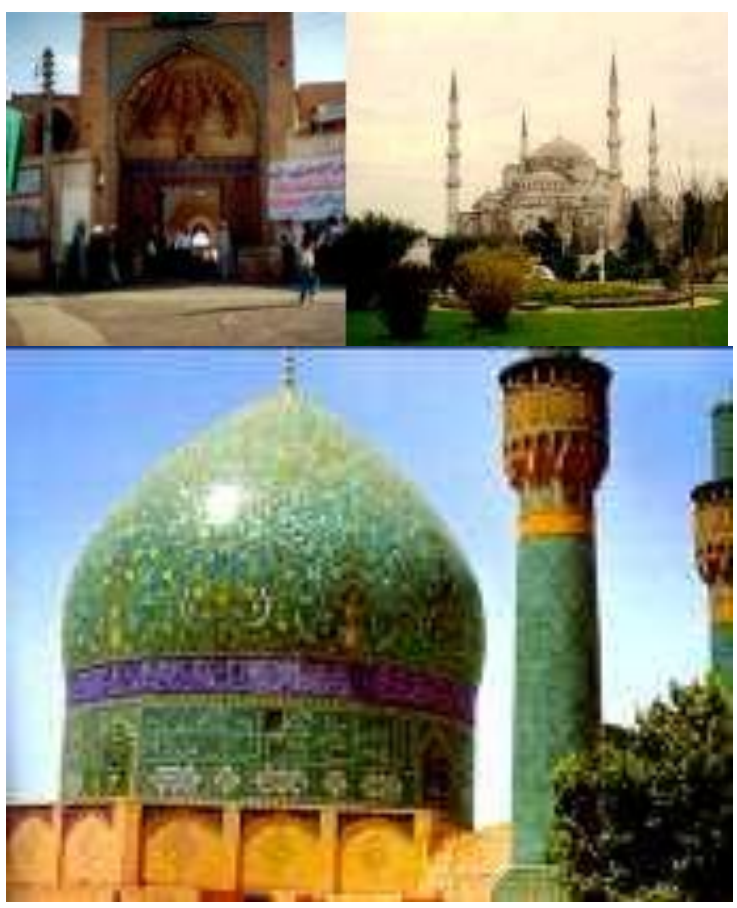

Figure 2: Masjid UniversitiTeknologi Malaysia with the copied elements: Blue Gate in Iran, the Tower of Turkey's Blue Mosque and the Dome of the Masjid-i Shah in Isfahan.

Issues Concerning the Selection of Building Typology in the Context of Ritual and Secular Worship

One of the major factors that influences the traits and characteristics of Islamic art is the selection of building and type of buildings used for the study. A common example of a building used by students when talking about Islamic art is the Mosque. This is a great pity because the study of Islamic Art buildings uses worn methods and Western approaches to understand and study the architecture.

Experts studying the art of buildings with a religious character usually see a building of religious worship or trust. This is typical of the character of Western culture, in particular Christian culture, which makes a separation between things earthly and heavenly. This creates a problem because religion and worship are rights and obligations of every individual and are separate from their secular lives. In studying Christian architecture, Western scholars and researchers usually examine Christian churches and other religious buildings usually used this perspective. This has been said by Ismail Faruqi in the following:

"The history of religions has known two influences that sought to reduce its jurisdiction by limiting the data that constitute its subject matter: one was to attempt to redefine the religious datum in a restricted and narrow manner, and the other was an isolationist policy observed vis-a-vis Judaism, Christianity and Islam."

"The attempt to limit the jurisdiction of phenomena of religions by giving the religious datum a narrow definition led to theories that have tried to isolate the religious element and to identify it in terms of "the religious", "the holy", "the sacred". The problem these theories faced was primarily the reductionist's analysis of the religious phenomenon into something else that would lend itself more readily to his kind of investigation." "7

However, in Islam, this separation is difficult to apply, as there is no separation between religious and secular issues. Islam teaches that a life must be mixed and integrated with the world and hereafter. Things heavenly and spiritual for a Muslim should be reflected in the daily work and social interaction among Islam's adherents. Likewise, all activities in the world in any form must have the character and spirit in heaven and happiness in the hereafter. Therefore, studies that take the mosque as the only example of the typology of Islamic architecture often exclude the framework and spirit of Islam itself from the discussion.

\section{Comparison between Value and Object Approaches} Another issue in the study of Islamic architecture is the approach of the object. The approach is usually a direct approach using a particular form (generally taken from Islamic buildings in the past) to be used in the design and study of Islamic architecture in the present.

The value approach usually consists of research and exploration of values or of the basic principles of Islam and then it was developed into a theory of building design and development. In the architectural profession, the product of these two approaches is the same which is the building. However, the process of thinking creates different stages of exploration which make lots of different. This make the approach to the object must be improved and must move from the physical aspects of the building to focus on non-physical aspects of the building.

In its application-it is more difficult to apply, but offers added value-this approach allows for 
broader development because it is not tied to a particular object or objects but has strong roots through a long process of thinking. Examples of writing that seek to provide a new language of architecture based on the values of Islam can be seen in the writing of Mohammad Tajuddin. In his paper entitled 'An Alternative Discourse on Islamic Architecture: The Compatibility of Wright's Organic Architecture with the Sunnah', he tried to give a new language to Islamic architecture by taking a lesson from the values of organic architect Frank Lloyd Wright ${ }^{8}$. The values of organic architecture put Wright in the context of the natural environment and respect for God and convey an idea of architecture that provides democracy at all levels and to all people of the same degree. They promote integration and unity of religious activities (worship) with community activities (muamallah). Studies conducted exploring the ideas of organic architecture, as mentioned earlier, explain how they explored, developed, and applied the designs. An application of the values of organic architecture becomes one reference in the future development of Islamic architecture.

\section{The Reminders of Sustainability in Islamic Architecture \\ God created human as caliph on this} earth. Caliph means leader, care-taker and guardian. Therefore humans have

an obligation to maintain, preserve and conserve this natural for future generations. Today we see a lot of damage that occurs in the earth caused by human behavior as revealed by Allah following:

"Mischief has appeared on land and sea because of (the meed) that the hands of men have earned, that (Allah) may give them a taste of some of their deeds: in order that they may turn back (from Evil). Say: "Travel through the earth and see what was the end of those before (you): Most of them worshipped others besides Allah."

Islam as seen in the Hadith below sees the whole of nature as a place of prayer that must be maintained to cleanliness and purity. Therefore as Muslims we need to preserve nature as we keep our place of prayer. From it, seen how the high concept of Islam in maintaining the environment.

"Hudhaifa reported: The Messenger of Allah (may peace be upon him) said: I have been made to excel (other) people in three (things)Our rows have been made like the rows of the angels and the whole earth has been made a mosque for us, and its dust has been made a purifier for us in case water is not available. And he mentioned another characteristic too. ${ }^{10}$
Sustainable in this writing has at least two contexts, which are natural contexts and social context. Natural context means that the development that we do should consider the needs of future generations. We must try to preserve nature for the future of next generation, therefore required an environmental impact planning of any development we do. This can be seen from Apostle's attitude which prohibit damaging the environment when war. From some of His Hadith, Apostle also encourages people to plant trees as a form of donate to the environment, as shown in the following Hadith:
"Jabir (Allah be pleased with him) reported Allah's Messenger (may peace be upon him) as saying: Never a Muslim plants a tree, but he has the reward of charity for him, for what is eaten out of that is charity; what is stolen of that, what the beast eat out of that, what the birds eat out of that is charity for him. (In short) none incurs a loss to him but it becomes a charity on his part." 11

Sustainable living in a social context means that we have to prepare a sustainable system of governance and political development. Replacement of the leader is a natural thing; something that actually needs to do is to prepare future leaders as much as possible, so that, when leadership changes, this transition do not disrupt the life of many people. Leadership is not a position which needs to be contested by a group of elites in community to material benefit, but it is a responsibility for every citizen as a form of responsibility and contribution to community.

In the world of architecture, these two principles have enormous implications. Natural sustainability teaches us to really pay attention the natural condition of site and environmental surrounding before designing a building. Materials selection and using of technology should really be considered before we make a change to site and then manage it. While social sustainability teaches us to be more pay attention to architectural language that we use in designing a building. Language of feudal architecture in the design of government or public buildings such assymmetry and a giant scale with excessively set back need to be avoided in order to create government or public building more democratic and familiar with community.

\section{Analysis of some design submissions by second year students of UKM in the project "Temporary Praying Platform". \\ "Temporary praying platform" is a project $2^{\text {nd }}$ year Architecture student of UKM in subject of Architectural Design Studio 3, code KKSB 2116. This}


project has the goal to design a temporary place of prayer with the design specifications are easily moved, reused, and folded. The project is selecting a location on the lake area and back of the Faculty Engineering and Built Environment the National University of Malaysia (UKM).

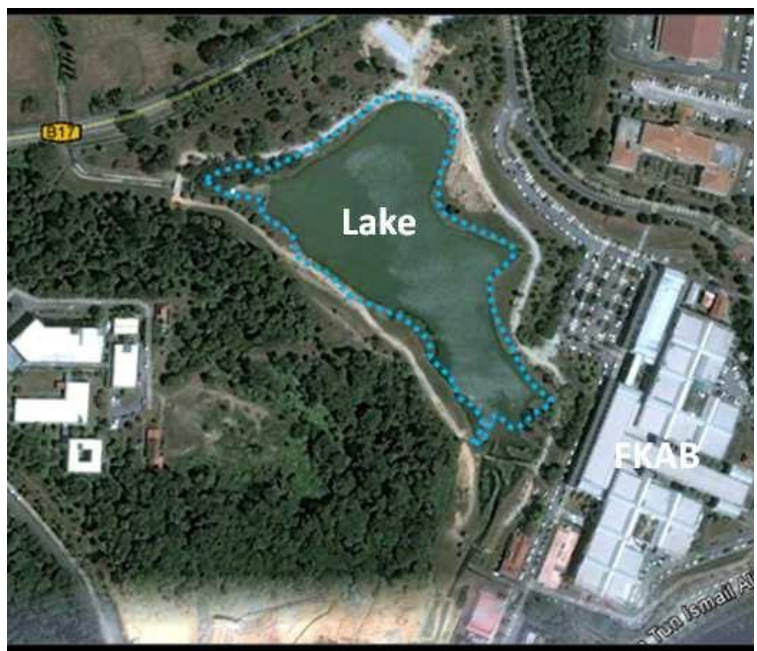

Figure 3: Lake of Faculty Engineering and Built Environment UKM (Sources: Google Earth Image 2011)

In this project the students have to optimize the potential of the environment by using design approach to Islam and sustainable architecture. Sustainable design is done by considering the design for sustainability and the natural site conditions still provide opportunities for future generations.

The following is an analysis of sustainable architecture from several designs submitted by ${ }^{2}$ nd year Architecture student UKM in the project "Temporary Praying Platform". The analysis is based on the development of design and building techniques which are both based on the consideration of sustainable architecture. In the design development there is some analysis, namely the concept and development of ideas, development of space that consisting of the space area and building space, then a systems of natural energy and sustainable. For building technique consists of an analysis of buildings material, the practicality of the design, structure and construction. Then there is also analyzes the social and economic analysis. The following is an analysis of project design on 2 nd year Architecture student UKM.

\section{Analysis of design development and sustainable innovation}

In this analysis have several points of analysis, namely the concept and development of ideas, development of space, and natural sustainable energy use.
The concept and idea development

The design concept has a very important position in a building design, because they are a main idea that will continue to be developed until it becomes a building product. In this project students are taking concepts related to Islam, such as the symbols in the prayer, takbir, bowing and prostration. The other concept that is more directed to themes of Islamic geometric, environmental and social. From the various concepts can be seen that the design approach being used are aligned with project descriptions that is a place of worship. From the overall concept is trying to use the basic principles hablumminallah, hablumminannas, and hablumminal'alam.

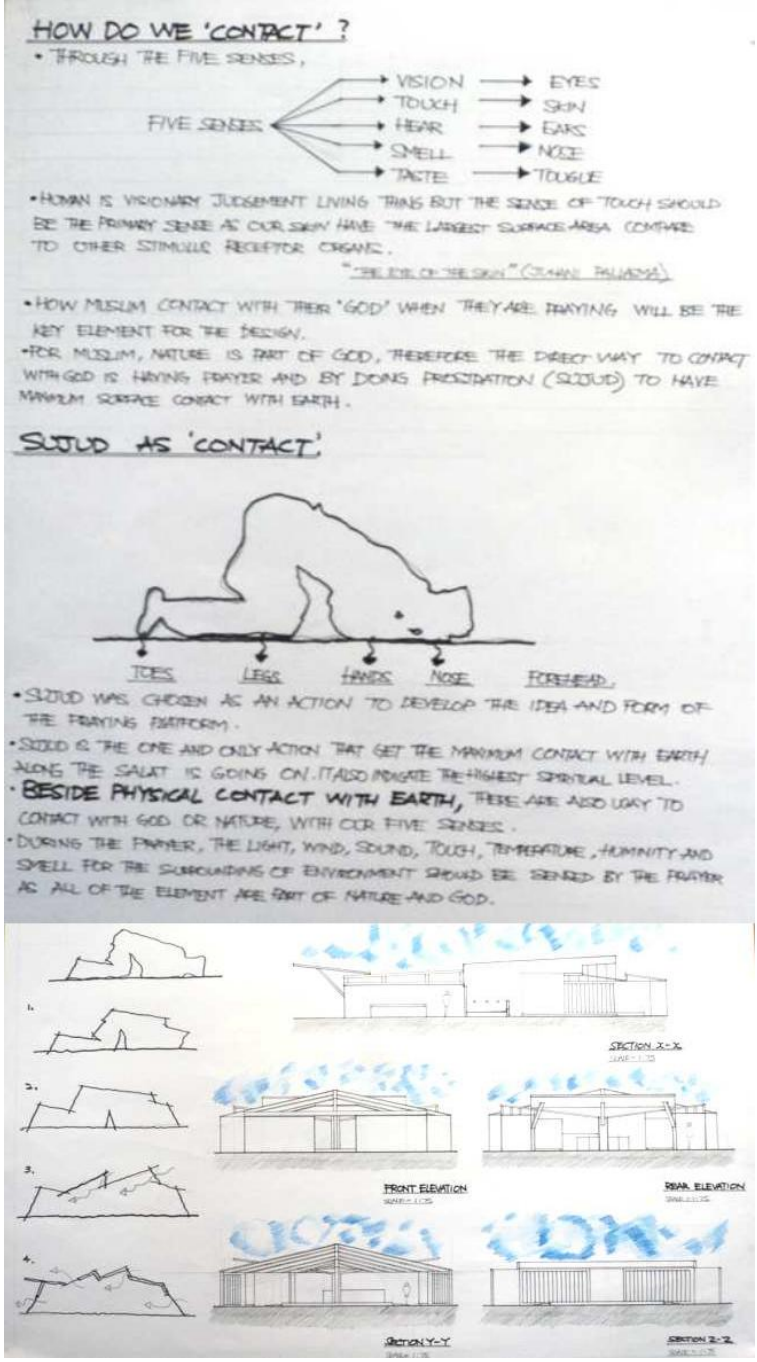

Figure 4: Concept and development of the idea of the symbol 'prostration'

(Sources: Design from $2^{\text {nd }}$ year Architecture Students "temporary praying platform")

One sustainable aspect in this project is how to design the building is not permanent and achieved good aspects of sustainability for the site or building that can be reused. Then building must be folded or to be more practical, those buildings 
are becoming easy for construction and demolished. Another aspect of sustainable building is able to move or relocate, this is the character of the building is not permanent or temporary. So after building no longer used, buildings can be demolished and folded and then moved to another place. Then if necessary will be used again. Some figures below are systems transformation and detail (movable, folded, re-used) temporary praying platform design from $2^{\text {nd }}$ year Architecture Students UKM.

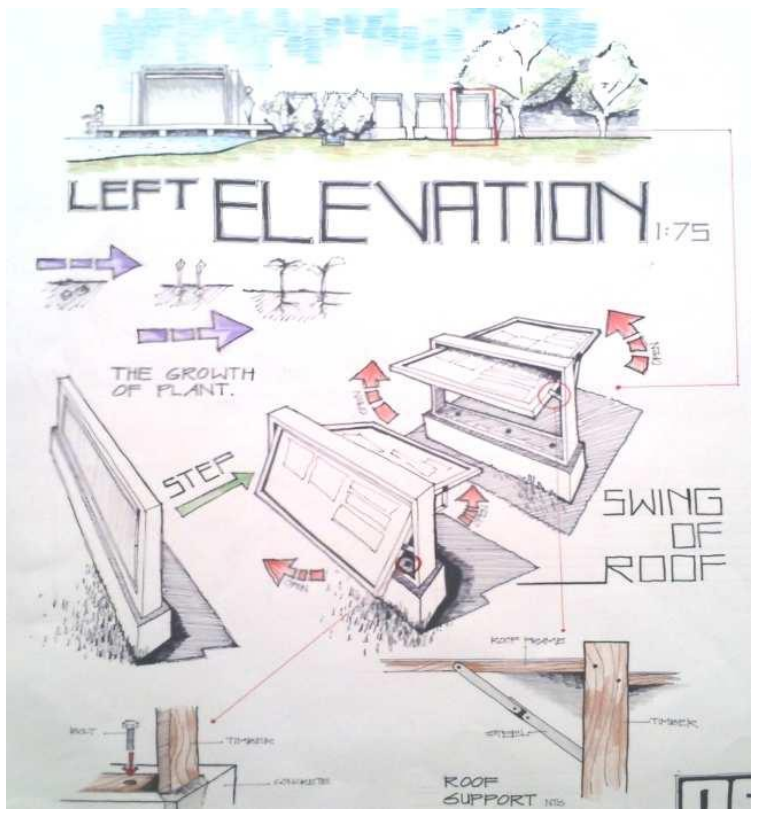

Figure 5: Folded system praying platform for information board

(Sources: Design from 2nd year Architecture Students "temporary praying platform")

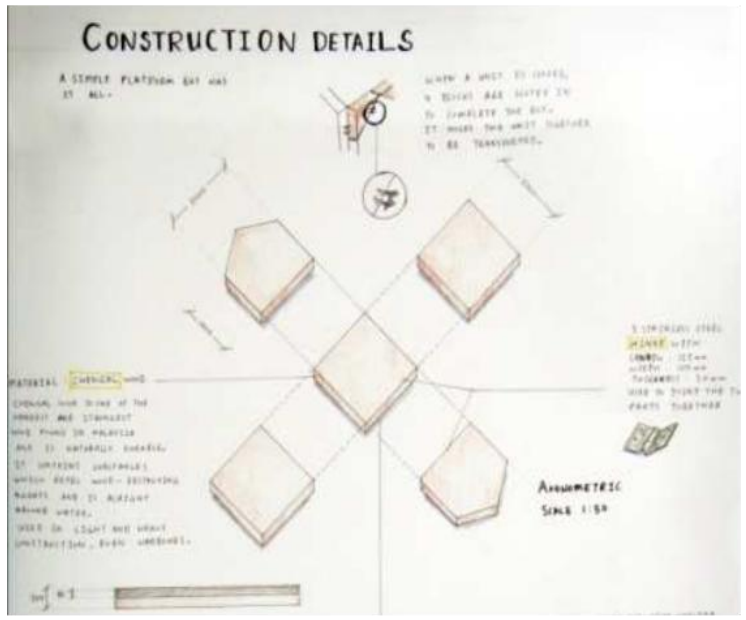

Figure 6: Folded and re-use system praying platform

Sources: Design from $2^{\text {nd }}$ year Architecture Students "temporary praying platform"

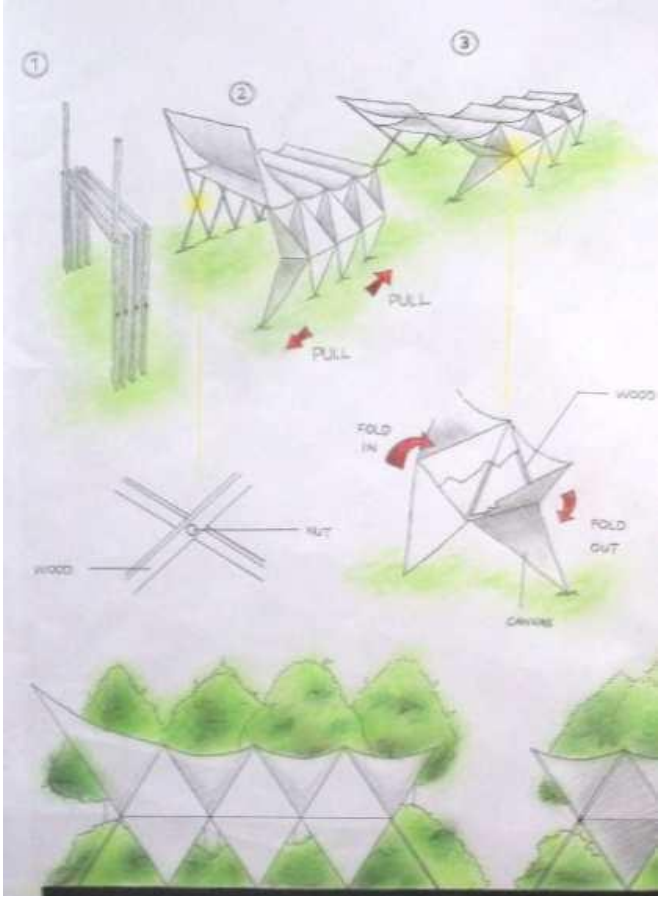

Figure 7: Folded and movable system with higttech design approach

Sources: Design from $2^{\text {nd }}$ year Architecture Students "temporary praying platform"

Some of these design requirements is one of the elements that supporting sustainable principles. With the fulfillment of these requirements makes the fundamental concepts hablumminallah, hablumminannas, and hablumminal'alam will be easily achieved and can be realized. Where the building trying to balance the relationship, the building used as a place to worship God Almighty with respect to the use of human interaction and appreciate the natural surroundings as a potential that needs to be optimized. One way to appreciate life is to preserve nature. According Prawoto $^{12}$ (2007) 'appreciate the tree is appreciate life.'

\section{Development of space}

Sustainability of an ecosystem is also determined by the arrangement of space. Space arrangement is how to determination and division of space must be done correctly and according to context and use of space. Development of space that does not consider these aspects can damage the existence of ecosystems. Therefore, in planning and designing of building should consider the first arrangement of space, where there is room for the space environment and space for building.

\section{Space area}

Space area consists of two types of space, building space and the space is not built or natural environment. In space there is a building built Faculty Engineering and Built Environment (FKAB) and a cafe building. As for the space that is not 
built. There are two spaces. First is the land space as parks and roads, and second is water space as the lakes and catchment areas.

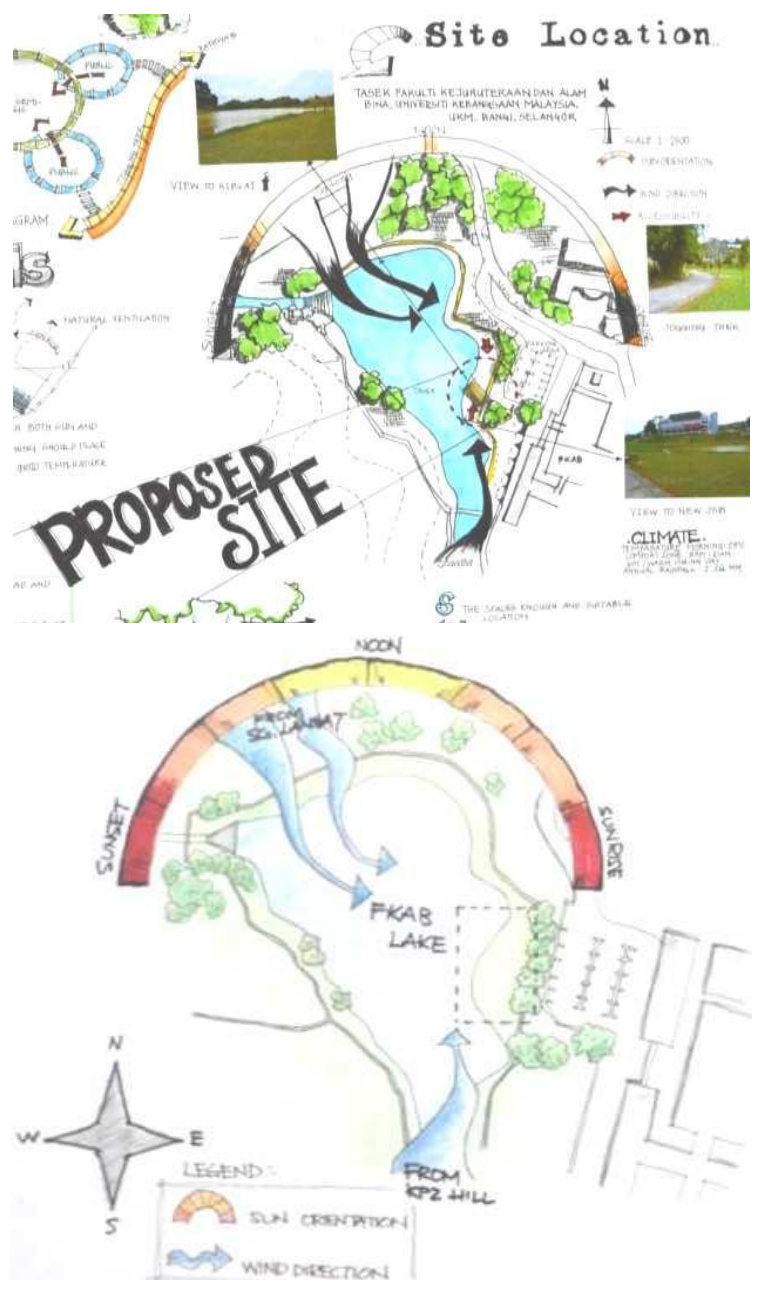

Figure 8: Analysis of site design and site selection for temporary praying platform

Sources: Design from $2^{\text {nd }}$ year Architecture Students "temporary praying platform"

Space that has been chosen by the student is on the eastern edge of the lake. The position has a goal to facilitate the achievement and circulation 'to' or 'from' location. With a prayer position facing the Kiblah, directly positions have been trying to maximize the view to the lake and maximize the potential of the area. Sustainable on this design concept was applied to maintain existing neighborhood and avoid land use over-exploited areas. The application by creating a design that has a dimension not too big. That space tailored to the needs and fulfillment activities in it. Then do designs that are not permanent and environmentally friendly.

\section{Building space}

As an Islamic-oriented building, arrangement of space in the building must consider the concept of "hijab". Hijab is setting the limits set by Islam in the relationship between man and woman who are not mahram. Then determine the sacred space as the main prayer place and dirty room or place ofablution.

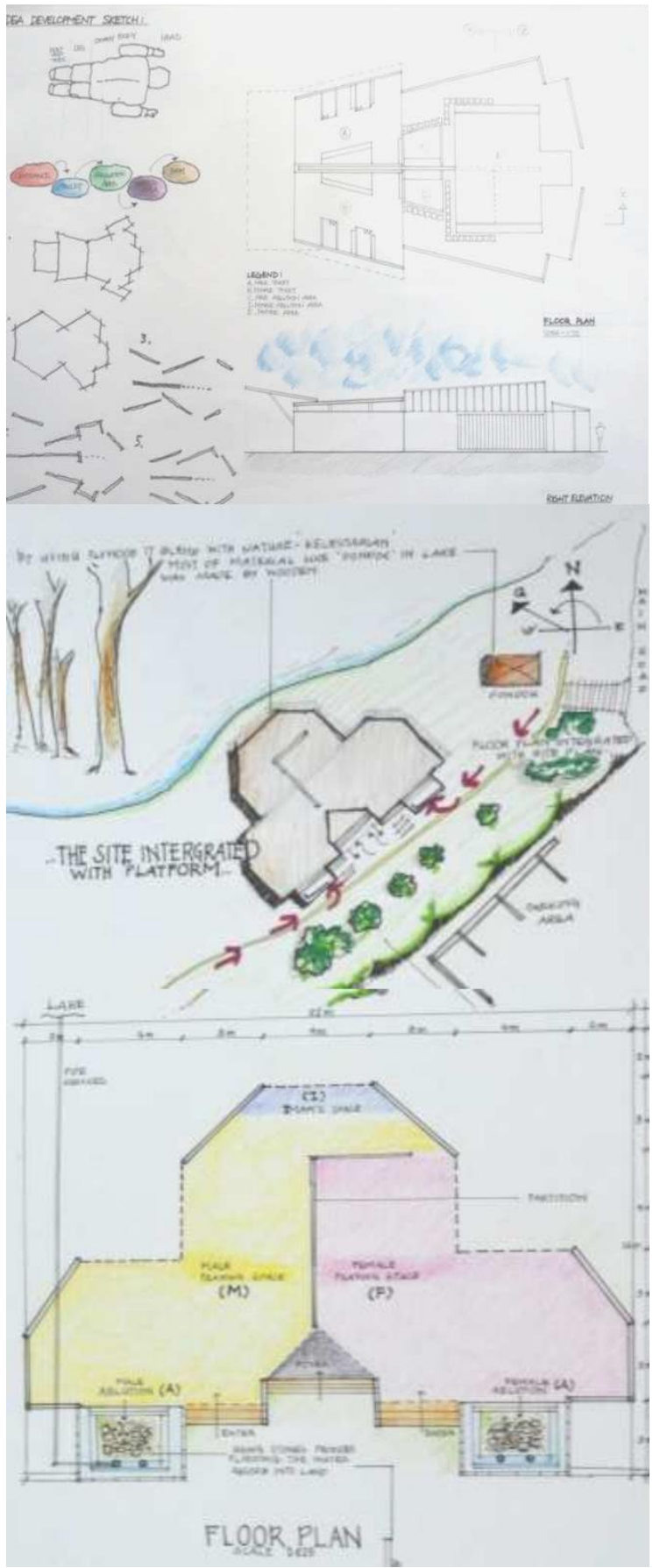

Figure 9: Analysis of the formation of space and spatial separation of men and women

Sources: Design from 2nd year Architecture Students "temporary praying platform"

The concept of sustainable can be done by setting a multifunctional space, which makes the space has a more complexes functions apart for prayer. When not used as a place of prayer, the building space can be used for other functions, for 
example for learning, discussion, site information, a break to enjoy the beauty of the lake, and others. This system can be called a function transformation and sustainable space. So the building will have benefits beyond more prayer time. Especially in this project is only focused on Aid prayers, where it is used only once a year. Therefore, spatial planning has an important role for the building to avoid wasteful and have more benefits.
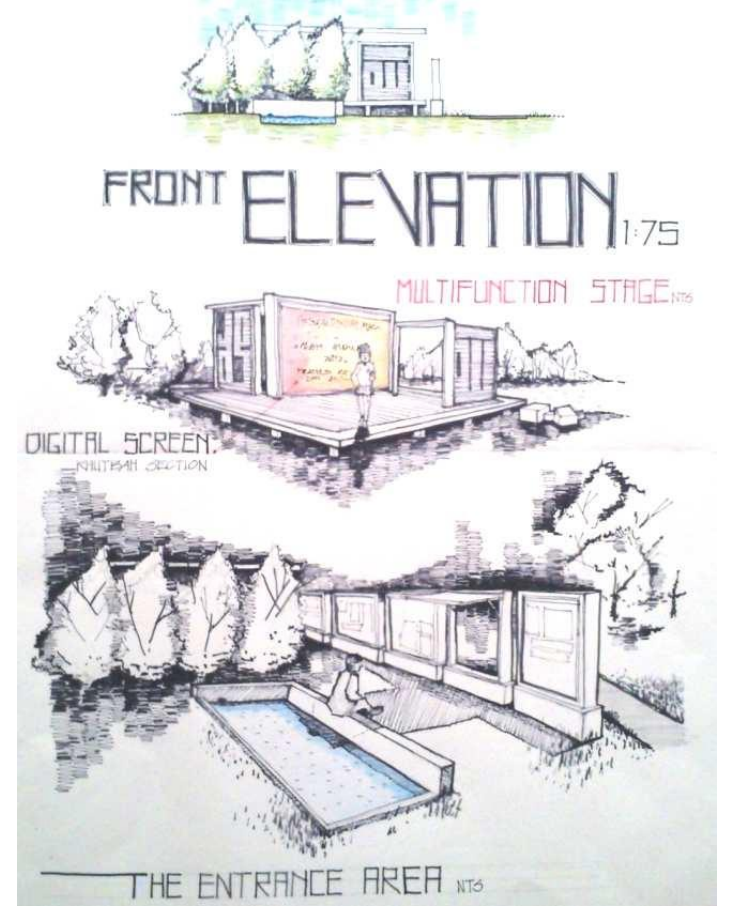

Figure 10: Formation of a multifunctional space (can use for information board)

Sources: Design from $2^{\text {nd }}$ year Architecture Students "temporary praying platform"

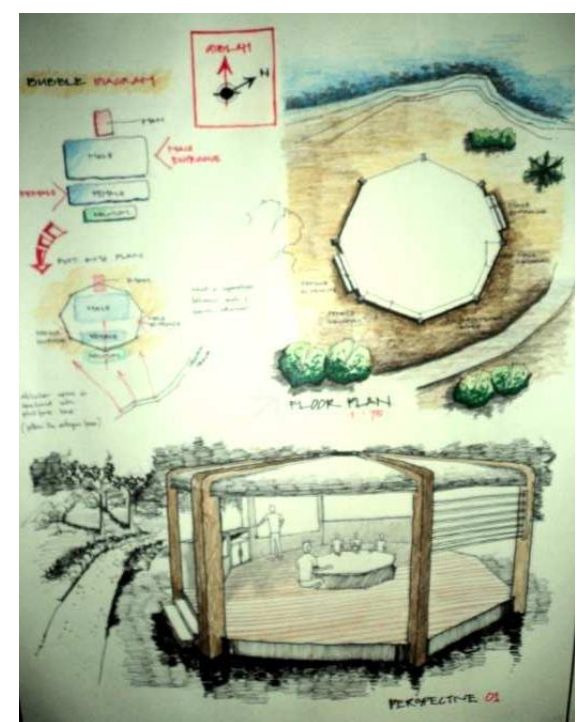

Figure 11: Formation of a multifunctional space (can use for discussion space)

Sources: Design from $2^{\text {nd }}$ year Architecture Students "temporary praying platform"
Using natural and sustainable energy

One important element in sustainable architecture is the energy, namely use and selecting an effective and efficient energy. Energy in sustainable architecture is very important in the future. The use of electrical energy is minimal, trying to utilize the natural energy that already exists in nature, such as sunlight during the day as a substitute for light. Then take advantage of natural air to circulate the air inside buildings as a replacement for Air Conditioner.

In the design of temporary praying platform energy is used trying to maximize the natural energy.The design should be able to control thepotentialenergy that is around the building like sunlight and wind. To utilize sunlight and wind building must be designed with openings and ventilation in accordance with considerations of light and wind direction.

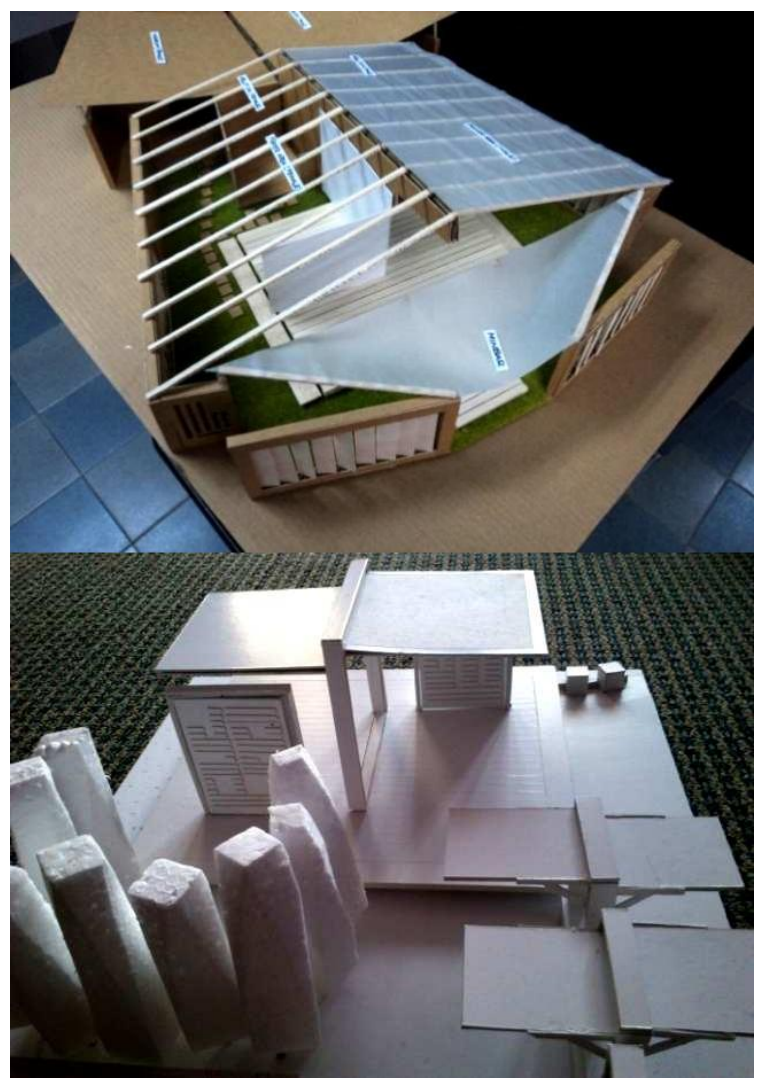

Figure 12: The design is open to maximize the potential of solar light and wind

Sources: Design from $2^{\text {nd }}$ year Architecture Students "temporary praying platform"

Excessive sunlight can make the building has a high temperature. The strong winds also will make the room not comfortable. Therefore there is need for a design that can control light and winds are needed in the building. To control light and wind can be done with the use of shading devices and gaps barriers to break down and reduce wind firmness and light entering the building. 


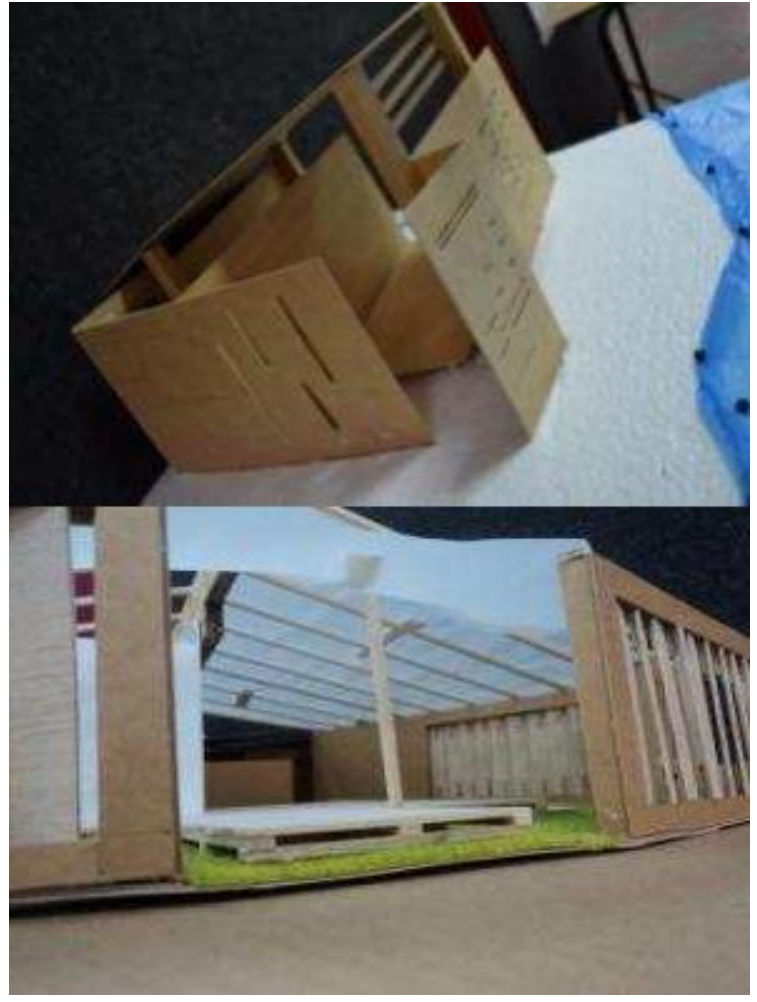

Figure 13: Shading devices and barriers to control light and wind on buildings

Sources: Design from $2^{\text {nd }}$ year Architecture Students "temporary praying platform"

Another big potential of the concept of sustainable in this area is the utilization of the lake water. Water conditions actually have a less good quality, the water brown and turbid. But if the presence of water is not used, lake water will only be a place for water disposal areas are not controlled in the long run. One way to use lake

water for this project is to use water filtration systems to restore the purity of water as before. The resulting clean water will be used as a potable water well wudlu. With the purpose of which is not too much, the water can be filtered as necessary, so it does not have the whole lake water is used. This situation will make this project can really benefit and utilizing the potential of the environment without destroying it.

Location is a potential for utilization of alternative energy sources, such as use of solar energy sources with solar panels and wind turbines use. According to Galloway (2004) the sun has a beautiful synergy with fuel cell-powered. For the utilization of wind can use a small wind turbine that has a low cost and quickly produce energy at lower wind area. According to Brower (1990) for small wind turbines, maintenance costs can be the deciding factor in site location to take advantage of marginal wind capabilities. In low wind sites, small wind turbines can consume a lot of energy from the wind.

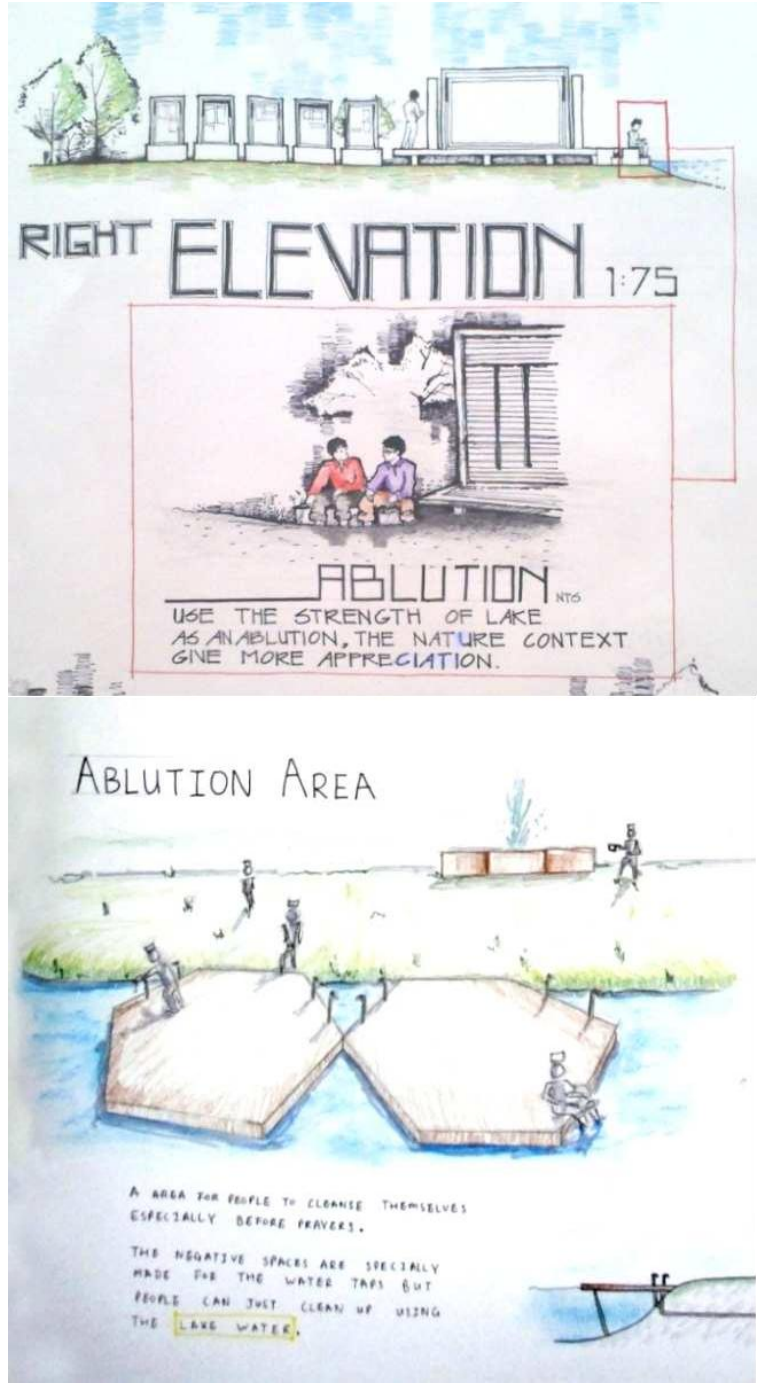

Figure 14: Use of lake water for ablutions Sources: Design from $2^{\text {nd }}$ year

ArchitectureStudents "temporarypraying platform"

With both systems the building will not need to use the existing electricity, but the building will be more independent and fulfilling the concept of sustainability. However, because this design is more temporary and practical, alternative energy is difficult to apply, especially equipment for solar electric panels and wind turbines have a high price.

\section{The technique of buildingsustainableinnovation}

In this section is an analysis that is more directed to the technical design. There are several points of analysis, such as building materials used, the practicality of the design, structure and construction of buildings.

\section{Building material}

In accordance with the specifications of the temporary buildings, materials used in buildings shall avoid permanent material such as concrete, because 
concrete is more difficult to movable and folded. Materials that can be used in the design to make it more practical and sustainable are bamboo and wood materials. According to Lopez (2003) Bamboo is a sustainable material because of its rapid growth, and has more capabilities than the wood and steel, so the use of bamboo materials to replace wood or steel.

Actually there are many other sustainable materials that can be used in this design, such as the use of waste materials and recycling. It will be more effective for the sustainability of the building material. An example is the design that uses a former wood formwork. Moreover, it can also use waste materials from factories and demolition of buildings.

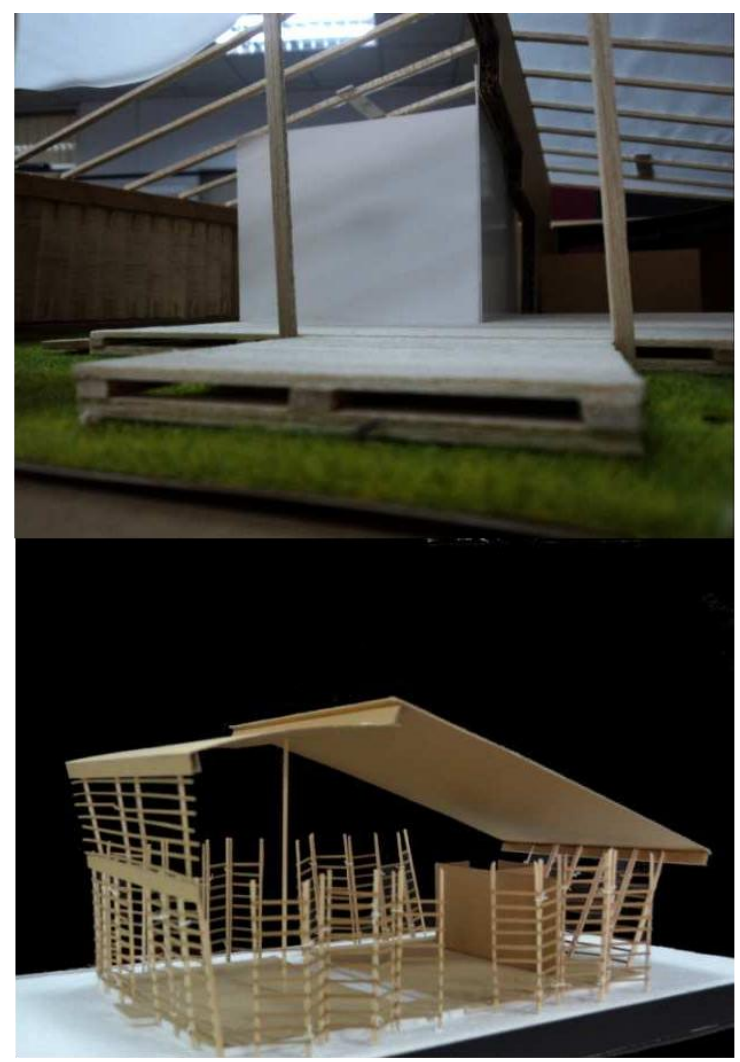

Figure 15: Using the materials of wood and bamboo as a sustainable material

Sources: Design from $2^{\text {nd }}$ year Architecture Students "temporary praying platform"

\section{Practicality of the design}

This project is not design a complex building that has complete elements such as building standards. This project is more simple and practical because only a "platform". Moreover, design only a temporary building that can be moved, folded and reused. Therefore, the building must have a value of practicality to constructed and demolished easily. So here is a challenge for students to design a building that has a maximum design exploration but more practical and sustainable.

\section{Structure and construction}

Practicality of design makes the structure becomes more simple and minimalist. But the construction must still be considered because the building must also meet safety aspects for its users. The structure and construction of buildings can be applied more innovative as a building structure and also as architectural elements. This will make the structure has more value and aesthetics, so that the building would be more efficient and effective.

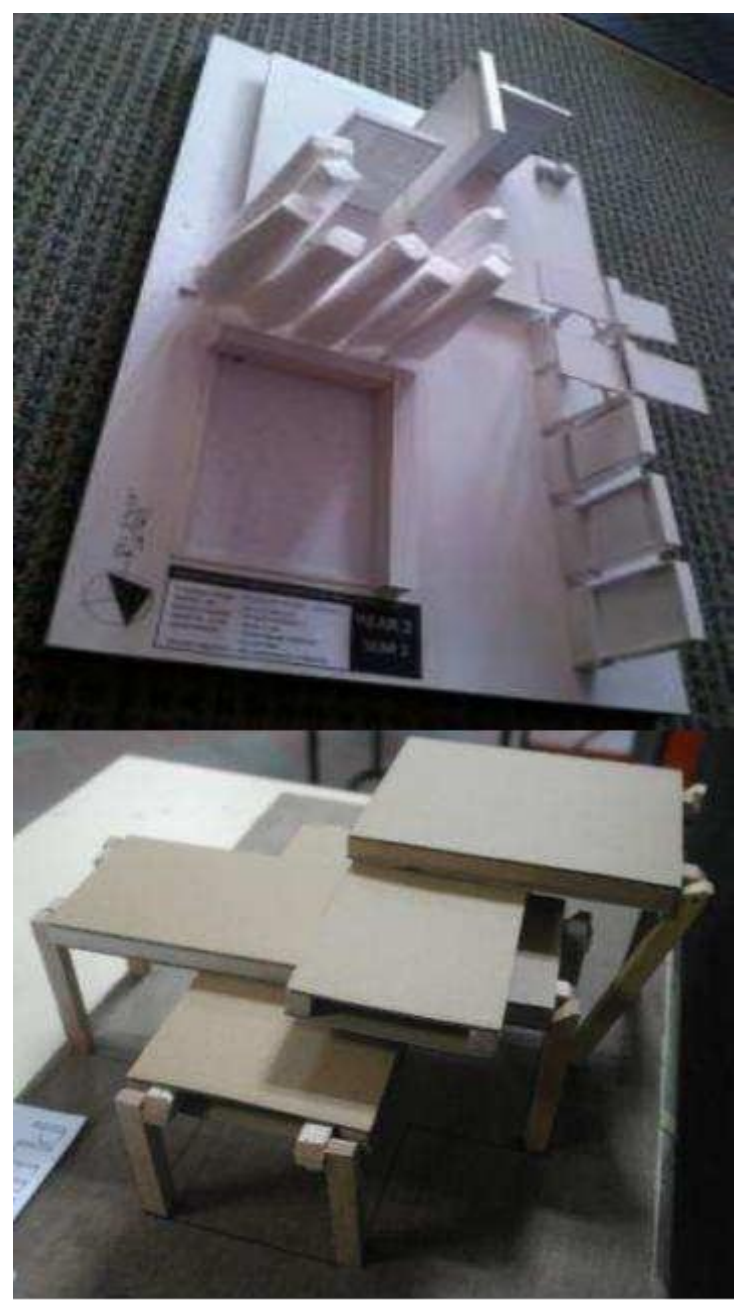

Figure 16: Concept design and practicality of building structural systems

Sources: Design from $2^{\text {nd }}$ year Architecture Students "temporary praying platform"

\section{Analysis of social life}

The easy accessibility and circulation is a factor to be considered in this design. Project site has a considerable distance with FKAB building, so the design "temporary praying platform" should be easily accessible and attractive to be able the visitors come and use the building facilities. 
Social aspects such as maintaining the continuityof interaction and social activities also should be considered. One function of the building is as social control. Thus planning and design planning should be able to meet these aspects. One example is the social interaction between men andwomen who are distinguished in a way that nodiscrimination.

Then create a building that has more moral and humane values. Building that allows users and provides more benefits. Do not build buildings dangerous and difficult. Sustainable architecture here has a major influence for social sustainability within and outside the building. Therefore, to maintain the continuity of the building and the environment must also maintain the existing balance of social interaction in buildings.

\section{Economic analysis}

According Prawoto ${ }^{13}$ (2007), The easiest things that architect can do in creating a sustainable architecture by saving the money are use a local material and skill, use a second-hand material and the old component, use a recycled material without any waste, design a room in many function, and design an open plan.

Economic analysis is used to maintain the continuity of the building. One system that can be used are the building has a complex function, which is in addition to functioning as a place of prayer also serves as a place of information about products or other that can be used as building management. Because the buildings still need care and management.

\section{Conclusion}

Humans as caliph on earth have a responsibility to safeguard the nature. Much damage has already occurred in nature that demands we should be more concerned about the existence of nature for now. Maintaining and preserving nature is actually a form of human worship to God Almighty. Sustainable architecture is one way to maintain the balance of nature and human social condition.

In this case, $2^{\text {nd }}$ year Architecture Students UKM trying to apply the concept of sustainable architecture in design "temporary praying platform" with the composition, clarity of design information, focus on each element sustainable and Islamic architecture. The design has been developed from ideas based on Islamic principles by balancing the relationship of God, man, and nature (hablumminallah, hablumminannas, and hablumminal'alam).
Sustainable architecture is applied in the design development and sustainable building techniques innovative. Creating a design that can support the sustainability of human nature and future generations by balancing the use of space and building area, utilize and maintain the potential of the natural environment. Then create a building design with an innovative system of natural energy such as maximizing the potential of sunlight, wind flow, and lake water. Next is the selection and use of sustainable materials are easily recycled, structure and construction of effective and efficient as wood, bamboo and waste materials that can be used again.

Next is to keep the continuity of social relationships. The social aspect is part of a sustainable that regulating human social interaction relationships with the building. Then create a building that has more moral and humane values. Building that allows users and provides more benefits. Do not build buildings dangerous and difficult, but trying to create a building that brings benefit and transcendence of tawheed to increase the faith and taqwa for building users.

\section{References}

1 Creswell. KAC (1968), A Short Accoumt of Early Muslim Architecture, p. 1

2 Creswell.KAC (1968), A Short Accoumt of Early Muslim Architecture, p. 3

3 Ismail Serageldin (1989), Faith and the Environment: An Inquiry into Islamic Principles and the Built Environment of Muslims, hal 213.

4 Proceedings of an International Seminar: Sponsored by the Aga Khan Award for Architecture and The Indonesian Institute of Architect 15-19 October 1990

5 Curtis, William JR (1982), Modern Architecture since 1900, hal 14.

6 Curtis, William JR (1982), Modern Architecture since 1900, hal 118.

7 Al Faruqi Ismail (1992), Al Tawhid: Its Implementation for thought and life, hal 416417.

8 Mohamad Tajuddin bin Haji Mohamad Rasdi, An Alternative Discourse on Islamic Architecture : The Compatibility of Wright's Organic Architecture with the Sunnah, kertas kerja pada mAAN Conference, National University of Singapore 4-6th September, 2002

9 QS Ar-Rum:41-42

10 Sahih Muslim Vol. I, page 265

11 Sahih Muslim, Vol. III, page 818

12 Prawoto, Eko (2007). "Kearifan Lokal sebagai Tumpuan Berarsitektur”. Seri Rumah Ide. Gramedia; Jakarta

13 ibid 